\title{
A Review of Current Health Education Theories
}

\author{
Kathy A. DeBarr \\ University of Illinois at Springfield
}

\begin{abstract}
This article presents a review of current theories and models in health education. Articles published in 2003 in the American Journal of Health Education, the American Journal of Health Behavior, Health Education and Behavior, Health Education Research, and the International Electronic Journal of Health Education, were reviewed. Concepts and constructs for each theory and model used are presented. The three predominant theories and models in this literature, The Transtheoretical Model (Stages of Change Theory), the Theory of Reasoned Action/Planned Behavior, and the Social Cognitive Theory are examined in greater detail.
\end{abstract}

(C) 2004 Californian Journal of Health Promotion. All rights reserved.

Keywords: theory, health education, health behavior, theoretical models

At times, beginning and even accomplished practitioners fail to acknowledge that much of what they do in their daily activities is rooted in a tremendous amount of study and research on the part of pioneers who went before them. Often in the search for practical ideas, theory is treated dismissively. It's interesting, but academic. Practitioners frequently succeed at intuiting the concepts, constructs and relationships of behavior, and applying this knowledge without recognizing that what they are doing has a basis in theory. This however, is a much less efficient approach than beginning with a conscious theoretical base from which to draw, and having that base to illuminate our work.

Theory plays an essential role in Health Education as a profession. According to Upton (1970, as cited in Taub, 1998), theory is one of the defining characteristics of a profession. The Coalition of National Health Education Organizations (CNHEO) publication, "The Health Education Profession in the 21st Century: Progress Report 1995-2001,” states that "Dynamic and Quality practice and research applies state-of-the-art theory and technology in the design, implementation, and evaluation of health education programs" (2001, p. 44). Theories and models are among health educators' most useful tools as they tackle the challenges of: a) needs assessment, b) program planning, c) program implementation, d) program evaluation, e) coordination of services, f) acting as a resource of health information, and g) communicating needs, concerns, and resources outlined in the Framework (Alperin \& Miner, 1993; National Task Force on the Preparation and Practice of Health Educators, 1985).

According to Babbie (2003), theory is defined as "A systematic explanation for the observations that relate to a particular aspect of life" (p. 12). Models on the other hand are best defined as "... a subclass of theory” (McKenzie \& Seltzer, 2001, p. 138). While theories are organized around ideas, concepts, and constructs, models are representations of theory. "Models provide the vehicle for applying the theories" (McKenzie \& Seltzer, 2001, p. 139). A theory, capable of full explanation of something as complex as human behavior, would be far too cumbersome to be useful. And thus we come to the criteria for useful theory: internal consistency, parsimony, plausibility, pragmatism and ecological validity (Glanz, Lewis, \& Rimer, 1997). The elegant simplicity required of theory necessitates that health education practitioners are conversant with a number of theories, 
enabling them to choose the most appropriate for the specific situation (Glanz, Lewis, Rimer, 1997).

The purpose of this article is to provide an overview of the theories and models currently being used in the field of health education. To address the issue of currency, the author reviewed theory- based articles published in 2003 in the following journals: the American Journal of Health Education, American Journal of Health Behavior, Health Education and Behavior, Health Education Research, and the International Electronic Journal of Health Education. Seventeen different theories were used to explain a wide variety of human behaviors, including pedestrian safety, physical activity, obesity, drug use, sexual behaviors, violence, vaccinations, organizational challenges, osteoporosis prevention, condom use, alcohol abuse, racial, ethnic and gender disparities, leisure activities, sunscreen use, use of complimentary and alternative medicine, tobacco use, sugar restriction, nutrition education, smoking, chronic illness management, hormone replacement therapy, soft drink consumption, environmental policy, family planning, and screening for colorectal cancer. These articles have been indexed in Appendix A, according to their theoretical base.

Some of the articles reviewed have their base in more than one theory or model. In 2003, stage theories/models were used most frequently. The Transtheoretical Model/ Stages of Change Theory served as a base for 17 articles, while the Theories of Reasoned/Action and Planned Behavior were the focus of 12 articles. Social Cognitive Theory/Social Learning Theory, which is used for understanding interpersonal health behavior was a base for 11 of the articles. The rest of the theories were cited five times or less. These include the Diffusion of Innovation Theory (five), Social Support/Social Capital (four), Health Belief Model (four), Coping Theory (two), Organizational Theory (two), and the remaining theories with one article each-Cognitive Dissonance Theory, the Elaboration Likelihood Model, Locus of Control, Piaget's
Theory of Child Development, the Precaution Adoption Model, the Precede-Proceed Model, Protection Motivation Theory, Systems Theory, and the Theory of Interpersonal Behavior. Three theories/models, the Transtheoretical Model alternatively known as the Stages of Change Theory, the Theory of Reasoned Action/Planned Behavior, and the Social Cognitive or Social Learning Theory, accounted for over half of the theoretical applications in these selected health education journals. Therefore, within this article, we will focus on these three theories/models. But first, we will examine four distinct categories of health theories and models: individual health behavior, interpersonal health behavior, group intervention, and staged models and theories.

The individual health behavior theories include Godfrey Hochbaum and Irwin Rosenstock's, Health Belief Model (Strecher \& Rosenstock, 1997), Leon Festinger's Cognitive Dissonance Theory (1957; Glanz, Lewis, \& Rimer, 1997), Icek Ajzen and Martin Fishbein's Theory of Reasoned Action (1969, 1970, 1977, 1980; Ajzen, 1988, 1991) which in 1988 was extended to the Theory of Planned Behavior (Ajzen, 1988, 1991), and R. W. Rogers' Protection Motivation Theory (Maddux \& Rogers, 1983, Rogers, 1983, as cited in Brouwers \& Sorrentino, 1983). See Table 1.

All of these theories seek to interpret or analyze health behaviors at the individual level, where intention is independent of the overt actions of others. Among this group of theories, Festinger's (1957) Cognitive Dissonance theory is noticeably different. Festinger's work does not focus on outcome expectation or threat, but instead focuses on the consonance between thought and action. Festinger posited that when this equilibrium is disrupted, one acts to restore the balance. Either the behavior or the attitude must change so that they are in concert with one another. The remaining theories make outcome expectations explicit as constructs, by assessing health threats, susceptibility, and the potential for efficacy of action. 
Table 1

Individual Health Behavior Theories/Models

\begin{tabular}{|c|c|c|c|}
\hline Theory & Originator(s) & Field of Study & Key Concepts and Constructs \\
\hline $\begin{array}{l}\text { Health Belief Model } \\
\text { Source: Strecher \& } \\
\text { Rosenstock, } 1997\end{array}$ & $\begin{array}{l}\text { Godfrey } \\
\text { Hochbaum } \\
\text { Irwin } \\
\text { Rosenstock, } \\
\text { 1950’s }\end{array}$ & Psychology & $\begin{array}{l}\text { Perceived threat } \\
\text { Perceived susceptibility } \\
\text { Perceived severity } \\
\text { Benefits and barriers to taking action } \\
\text { Cues to action } \\
\text { Self-efficacy }\end{array}$ \\
\hline $\begin{array}{l}\text { Cognitive Dissonance } \\
\text { Sources: Festinger, } \\
\text { 1957; Glanz, Lewis, } \\
\text { \& Rimer, } 1997\end{array}$ & $\begin{array}{l}\text { Leon Festinger } \\
1957\end{array}$ & $\begin{array}{l}\text { Social } \\
\text { Psychology }\end{array}$ & $\begin{array}{l}\text { Cognition } \\
\text { Conflict } \\
\text { Consonnance } \\
\text { Dissonance } \\
\text { Motivation. } \\
\end{array}$ \\
\hline $\begin{array}{l}\text { Theory of Reasoned } \\
\text { Action/Planned } \\
\text { Behavior } \\
\text { Sources: Ajzen \& } \\
\text { Fishbein 1969, 1970, } \\
\text { 1977, 1980; } \\
\text { Ajzen, 1988, } 1991\end{array}$ & $\begin{array}{l}\text { Icek Ajzen \& } \\
\text { Martin } \\
\text { Fishbein } 1969 \\
1988 \text { TPB } \\
\text { evolved from } \\
\text { TRA }\end{array}$ & Psychology & $\begin{array}{l}\text { Behavioral intention } \\
\text { Attitude } \\
\text { Outcome expectancy } \\
\text { Evaluation of likelihood of outcome } \\
\text { expectancy } \\
\text { Subjective norm } \\
\text { Normative beliefs } \\
\text { Motivation to comply } \\
\text { Perceived behavioral control } \\
\text { Control beliefs } \\
\text { Actual behavioral control }\end{array}$ \\
\hline $\begin{array}{l}\text { Protection Motivation } \\
\text { Theory } \\
\text { Sources: Rogers, R. } \\
\text { W. 1975., Maddux, J. } \\
\text { E., \& Rogers, R. W. } \\
\text { 1983., Rogers, R. W. } \\
1983 \text { as cited in } \\
\text { Brouwers, M.C. \& } \\
\text { Sorrentino, R.M. } \\
1983\end{array}$ & $\begin{array}{l}\text { R W Rogers } \\
1975\end{array}$ & $\begin{array}{l}\text { Social } \\
\text { Psychology }\end{array}$ & $\begin{array}{l}\text { Threat appraisal } \\
\text { Coping appraisal } \\
\text { Severity } \\
\text { Vulnerability } \\
\text { Self-Efficacy } \\
\text { Response-Efficacy }\end{array}$ \\
\hline
\end{tabular}

Among the interpersonal health behavior models are Alfred Bandura's Social Cognitive Theory (Bandura \& Walters, 1963; Bandura, 1969, 1977a, 1977b), H. C. Triandis' Theory of Interpersonal Behavior (1977, 1980, 1994, 1995), the combined works of Gordan Caplan (1974), S. Cobb (1976), J. S. House (1981), R. L. Kahn and T. C. Antonucci (1980) in social support, and coping, the works of Barbara S. Wallston, Kenneth A. Wallston, Gordan D. Kaplan, and S. A. Maides (1976; Wallston Maides, \& Wallston (1976).) concerning Locus of Control, and Richard Petty \& John Cacioppo's Elaboration Likelihood Model (Cacioppo, 1979, 1981, 1986, 1986a; Cacioppo \& Petty, 1979). See Table 2. These theories move one step beyond the individual health behavior theories to consider the influence of other persons on health behavior. These theories share several concepts not only with the group theories, but also with the individual health theories. See the table in Appendix B. 
Table 2

Interpersonal Health Behavior Theories/Models

\begin{tabular}{|c|c|c|c|}
\hline Theory/Model & Originator(s) & Field of Study & Key Concepts/Constructs \\
\hline $\begin{array}{l}\text { Social Cognitive Theory } \\
\text { Sources: Bandura \& } \\
\text { Walters, 1963; Bandura } \\
\text { 1977a, 1977b, 1986, } \\
\text { 1994; Pajares } 2002\end{array}$ & $\begin{array}{l}\text { Albert Bandura } \\
1963\end{array}$ & Psychology & $\begin{array}{l}\text { Personal Factors (Cognitive, affective, } \\
\text { and biologic) } \\
\text { Behavior } \\
\text { Environmental factors } \\
\text { Reciprocal determinism } \\
\text { Triadic reciprocality between personal } \\
\text { factors, behavior, and environment. } \\
\text { Modeling } \\
\text { Vicarious learning } \\
\text { Self-efficacy }\end{array}$ \\
\hline $\begin{array}{l}\text { Theory of Interpersonal } \\
\text { Behavior } \\
\text { Sources: Triandis, H. C. } \\
(1977,1980,1994,1995)\end{array}$ & $\begin{array}{l}\text { H. C. Triandis } \\
\text { 1970's }\end{array}$ & Psychology & $\begin{array}{l}\text { Cognitive } \\
\text { Social } \\
\text { Personal factors } \\
\text { Habit } \\
\text { Intentions } \\
\text { Facilitating conditions } \\
\end{array}$ \\
\hline $\begin{array}{l}\text { Social Support, Control, } \\
\text { Stress, and Coping } \\
\text { Sources: Caplan, G. } \\
\text { (1974), Cobb, S. (1976), } \\
\text { House, J. S. (1981), } \\
\text { Kahn, R. L. \& } \\
\text { Antonucci, T. C. (1980). }\end{array}$ & $\begin{array}{l}\text { Caplan } 1974 \\
\text { Cobb } 1976 \\
\text { House } 1981 \\
\text { Kahn \& } \\
\text { Antonucci } 1980\end{array}$ & $\begin{array}{l}\text { Social } \\
\text { Psychology }\end{array}$ & $\begin{array}{l}\text { Supportive behaviors } \\
\text { Emotional support } \\
\text { Appraisal support } \\
\text { Informational support } \\
\text { Instrumental support } \\
\text { Social capital }\end{array}$ \\
\hline $\begin{array}{l}\text { Health Locus of Control } \\
\text { Sources: Wallston, B. S., } \\
\text { Wallston, K. A., Kaplan, } \\
\text { G. D., \& Maides, S. A. } \\
\text { (1976). Wallston, K. A., } \\
\text { Maides, S. A., \& } \\
\text { Wallston, B. S. (1976). }\end{array}$ & $\begin{array}{l}\text { Barbara S. } \\
\text { Wallston, } \\
\text { Kenneth A. } \\
\text { Wallston, } \\
\text { Gordan D. } \\
\text { Kaplan } 1976\end{array}$ & Psychology & $\begin{array}{l}\text { Expectancy } \\
\text { External locus of control } \\
\text { Health externals } \\
\text { Health internals } \\
\text { Internal locus of control } \\
\text { Powerful others } \\
\text { Reinforcement }\end{array}$ \\
\hline $\begin{array}{l}\text { Elaboration Likelihood } \\
\text { Model } \\
\text { Sources: Cacioppo, J. T. } \\
\text { \& Petty, R. E. (1979), } \\
\text { Petty, R. E., } \\
\text { \& Cacioppo, J. T. } \\
\text { (1981), Petty, R. E., \& } \\
\text { Cacioppo, J. T. (1986a) } \\
\text { As cited in McNeil \& } \\
\text { Stoltenberg, 1989. }\end{array}$ & $\begin{array}{l}\text { Richard Petty \& } \\
\text { John Cacioppo } \\
1979\end{array}$ & Psychology & $\begin{array}{l}\text { Persuasive communication } \\
\text { Central route to persuasion } \\
\text { Peripheral route to persuasion } \\
\text { Motivation to process } \\
\text { Ability to process } \\
\text { Nature of cognitive processing } \\
\text { Cognitive structure change } \\
\text { Central positive attitude change } \\
\text { Central negative attitude change } \\
\text { Peripheral attitude shift } \\
\text { Peripheral cue present } \\
\text { Attitude } \\
\text { Boomerang attitude } \\
\text { Persistence } \\
\text { Resistance } \\
\text { Behavioral prediction }\end{array}$ \\
\hline
\end{tabular}


Social systems, the third category of theory to be reviewed, included two articles concerned with social systems theory. One article specifically addressed General Systems Theory, which was first conceived by L. Von Bertalanffy (1950), (International Society for the Systems Sciences, n.d.). Dr. Bertalanffy was a biologist and a renowned theorist in the early 20th century. The General Systems Theory addresses the complexities and solutions of virtually every scientific field (International Society for the Systems Sciences, n.d.), but for our purposes in health education, it is applied to the sociocultural and psychological domains (Von Bertalanffy, 1976), and more specifically, to the field of social marketing (Sirgy, 1984).

The fourth grouping of health behavior theories contains what are referred to as stage theories. Piaget's Child Development Theory (Jean Piaget Society, n.d.) describes children's developmental stages from birth through age fifteen. Green's Precede-Proceed Model (Green \& Kreuter, 1991) is a comprehensive staged program planning model, extending from needs assessment through outcome evaluation. Only the final three models, Prochaska and DiClemente's Transtheoretical Model (Glanz, Lewis, \& Rimer, 1997; Kreuter \& Lezin, 2002; Zimmerman, Olsen, Bosworth, 2000), Rogers' Diffusion of Health Promotion Innovation (1983), and Weinstein's Precaution Adoption Model (1988), are concerned directly with following or predicting the progress of adoption of behavior changes. Within those three, there is an overlap of concepts, which can be readily seen through examination of Table 3.

Having reviewed the different groups of theoretical research currently being used in the specified health education journals this past year, let us turn to the three theories/models most frequently used therein. These include: The Transtheoretical/Stages of Change Model, the Theories of Reasoned/Action and Planned Behavior, and the Social Cognitive Theory/Social Learning Theory.

The Transtheoretical Model was first developed in 1983 by James O. Prochaska and C. C.
DiClemente (Glanz, Lewis, \& Rimer, 1997; Kreuter \& Lezin, 2002). The model derives from the profession of psychology and addresses five stages of behavior change. Precontemplation is denial or not being aware that a behavior puts one at risk. As one develops awareness of the situation, he/she begins Contemplation of taking action, considering all of the factors that go into making the decision to change a behavior. Progressing to the Preparation phase, one might line up social support, make plans of action, and purchase necessary accoutrements. The Action phase is the actual adoption of the new behavior, and the Maintenance phase is where one works to keep their acquired behavior on-track. Maintenance is a lifelong process. There is interplay between the stages, as they are not linear. As with any behavior modification regimen, occasionally one may slip back into the maladaptive behavior. Once the slip occurs, one re-enters the process. This model has the advantage of acknowledging that these slips do occur, and preparing people for these occurrences. Slips are considered mere eventualities, as they are expected, and are not seen as catastrophic events that might lead one to abandon the positive health behaviors one is attempting to acquire. Next we will examine the Theory of Reasoned Action/Planned Behavior.

Ajzen and Fishbein's Theory of Reasoned Action (1969, 1970, 1977, 1980) predates the eventual extension to the Theory of Planned Behavior by at least twenty years. These theorists began with the interesting notion that people behave the way that they do for a reason, and thus behavior is logical. If this holds true, we should be able to explain or predict human behavior. They began by positing that the best way to predict someone's actions, is to ask them what they intend to do within a reasonably proximal time range. Behavioral intentions are thus the best predictors of human behavior. They determined that the best predictors of one's stated behavioral intentions lie in attitude and subjective norm. According to Ajzen and Fishbein, one's attitude is best predicted by examining what he/she expects to be the outcome of a particular action, and his/her evaluation of the likelihood of this outcome. 
Table 3. Stage Theories

\begin{tabular}{|c|c|c|c|}
\hline Theory/Model & Originator(s) & Field of Study & Key Concepts/Constructs \\
\hline $\begin{array}{l}\text { Piaget's Child } \\
\text { Development Theory } \\
\text { Source: Jean Piaget } \\
\text { Society }\end{array}$ & $\begin{array}{l}\text { Jean Piaget } \\
\text { 1950's }\end{array}$ & $\begin{array}{l}\text { Biology } \\
\text { Philosophy }\end{array}$ & $\begin{array}{l}\text { Stages } \\
\text { 1) Sensorimotor stage (Birth to } 2 \text { Years) } \\
\text { 2) Preoperational stage (Ages 2-7) } \\
\text { 3) Concrete operations (7-11) } \\
\text { 4) Formal operations (11-15) }\end{array}$ \\
\hline $\begin{array}{l}\text { Precede-Proceed } \\
\text { Source: Green, L. \& } \\
\text { Kreuter, M. (1991). }\end{array}$ & $\begin{array}{l}\text { Lawrence } \\
\text { Green 1968- } \\
\text { early 80’s }\end{array}$ & $\begin{array}{l}\text { Health } \\
\text { Education }\end{array}$ & $\begin{array}{l}\text { Precede: Predisposing, Reinforcing, and Enabling } \\
\text { causes in Education, Diagnosis and Evaluation. } \\
\text { Proceed: Policy, Regulatory, and Organizational, } \\
\text { Constructs in Education and Environmental } \\
\text { Development } \\
\text { 9 Phases: } \\
\text { 1) Social diagnosis } \\
\text { 2) Epidemiologic diagnosis } \\
\text { 3) Behavior and Environmental diagnosis } \\
\text { 4) Education \& Organization diagnosis } \\
\text { 5) Administrative \& Policy diagnosis } \\
\text { 6) Implementation } \\
\text { 7) Process evaluation } \\
\text { 8) Impact evaluation } \\
\text { 9) Outcome evaluation }\end{array}$ \\
\hline $\begin{array}{l}\text { Transtheoretical Model } \\
\text { Stages of Change } \\
\text { Sources: Glanz, Lewis, } \\
\text { \& Rimer, 1997; } \\
\text { Kreuter \& Lezin, } 2002\end{array}$ & $\begin{array}{l}\text { James O. } \\
\text { Prochaska, } \\
\text { C. C. } \\
\text { DiClemente } \\
1983\end{array}$ & Psychology & $\begin{array}{l}\text { Stages } \\
\text { 1) Precontemplation } \\
\text { 2) Contemplation } \\
\text { 3) Preparation } \\
\text { 4) Action } \\
\text { 5) Maintenance }\end{array}$ \\
\hline $\begin{array}{l}\text { Diffusion of Health } \\
\text { Promotion Innovation } \\
\text { Source: Rogers (1995) } \\
\text { as cited in Clarke } \\
\text { (1999) }\end{array}$ & $\begin{array}{l}\text { Everett M. } \\
\text { Rogers } 1962\end{array}$ & Communication & $\begin{array}{l}\text { Stages of Technological Innovation: Knowledge, } \\
\text { Persuasion, Decision, Implementation, } \\
\text { Confirmation } \\
\text { Characteristics: Relative advantage, Compatability, } \\
\text { Complexity, Trialability, Observability } \\
\text { Adopter Categories: Innovators, Early adopters, } \\
\text { Early majority, Late majority, Laggards } \\
\text { Roles: Opinion leaders, Change agents, Change } \\
\text { aids }\end{array}$ \\
\hline $\begin{array}{l}\text { Precaution Adoption } \\
\text { Model } \\
\text { Source: Weinstein } \\
\text { (1988) }\end{array}$ & $\begin{array}{l}\text { Neil D. } \\
\text { Weinstein } \\
1988\end{array}$ & Psychology & $\begin{array}{l}\text { Stages: } \\
\text { 1) Unaware of issue } \\
\text { 2) Unengaged by issue } \\
\text { 3) Deciding about acting } \\
\text { 4) Decided not to act } \\
\text { 5) Decided to act } \\
\text { 6) Acting } \\
\text { 7) Maintenance }\end{array}$ \\
\hline
\end{tabular}


Subjective norm is a generalized construct, reliant upon one's normative beliefs (what significant others would have them do), and one's motivation to comply with the wishes of these significant others. General criticism of the model was levied that the theory did not take into account behaviors not under the volitional control of the subject.

This was remedied with the 1985 evolution of the theory to address this aspect as planned behavior. See Ajzen (1988) for a thorough treatment of the Theory of Planned Behavior. With the addition of perceived behavioral control (ability), we see its impact on intention, the reciprocal determinism between perceived behavioral control and subjective norm, between perceived behavioral control and attitude, and between attitude and subjective norm. Ajzen notes that actual behavioral control is dependent upon resources and opportunity (Ajzen, 1991).

The final theory to be reviewed is the Social Cognitive/Social Learning Theory advanced by Albert Bandura. Bandura advanced Social Learning Theory in 1963 (Bandura, 1963, 1977, 1986, 1994; Pajares, 2002), by introducing the concepts of modeled behavior and vicarious reinforcement as learning mechanisms. It wasn't until 1977 that he introduced the concept of self-efficacy into the theory (Bandura, 1977a, 1977b, 1986, 1994, Pajares, 2002). In 1986, Bandura introduced the idea of reciprocal determinism (Bandura, 1986, 1994; Pajares, 2002). Pajares (2002) states that Bandura's idea of reciprocal determinism is based in "the view that (a) personal factors in the form of cognition, affect, and biological events, (b) behavior, and (c) environmental influences create interactions that result in a triadic reciprocality." It was at this time that Bandura changed the name of the theory from Social Learning Theory to Social Cognitive Theory "...to distance it from prevalent social learning theories of the day and to emphasize that cognition plays a critical role in people's capability to construct reality, selfregulate, encode information, and perform behaviors.”

This article has provided a brief overview of several of the theories used in health education today. Although the theories were categorized here as individual, interpersonal, social systems, and staged theories, they could just have well have been organized around their many uses. They provide insight into every facet of program planning, implementation, and evaluation. They also provide us with the tools necessary to understand individual behavior, as well as the behaviors of populations we wish to serve.”

For those wishing a more complete treatment of theory as applied in health education, the texts by Glanz, Rimer, and Lewis entitled: Health Behavior and Health Education: Theory Research and Practice (2002), and Emerging Theories in Health Promotion Practice and Research: Strategies for Improving Public Health (Diclemente, Crosby, \& Kegler, 2002) are recommended. Another source produced by the National Institutes of Health is Theory at a Glance. For those wanting a quick overview of a variety of health behavior change theories and models, Kelli McCormack Brown has compiled a great deal of information that can be accessed at her web site.

\section{References}

Ajzen, I. (1988). Attitudes, personality, and behavior. Chicago: Dorsey Press.

Ajzen, I. (1991). The theory of planned behavior. Organizational Behavior and Human Decision Processes, 50, 179-211.

Ajzen, I., \& Fishbein, M. (1969). The prediction of behavioral intentions in a choice situation. Journal of Experimental Social Psychology, 5, 400-416.

Ajzen, I., \& Fishbein, M. (1970). The prediction of behavior from attitudinal and normative variables. Journal of Experimental Social Psychology, 6, 466-487.

Ajzen, I., \& Fishbein, M. (1977). Attitude-behavior relations: A theoretical analysis and review of empirical research. Psychological Bulletin, 84, 888-918. 
Ajzen, I., \& Fishbein, M. (1980). Understanding attitudes and predicting social behavior. Englewood Cliffs, NJ: Prentice Hall.

Alperin, M., \& Miner, K. R. (1993). Professional relevance: meeting the contemporary public health agenda. Journal of Health Education, 24, 299-304.

Babbie, E. (2003). The practice of social research (10th ed.). Belmont, CA: Thomson.

Bandura, A. (1977a). Self-efficacy: Toward a unifying theory of behavioral change. Psychological Review, 84, 191-215.

Bandura, A. (1977b). Social learning theory. Englewood Cliffs, NJ: Prentice Hall.

Bandura, A. (1986). Social foundations of thought and action: A social cognitive theory. Englewood Cliffs, NJ: Prentice Hall.

Bandura, A. (1994). Self-efficacy. In V. S. Ramachaudran (Ed.), Encyclopedia of human behavior (Vol. 4, pp. 71-81). New York: Academic Press. (Reprinted in H. Friedman (Ed.), Encyclopedia of mental health. San Diego: Academic Press, 1998).

Bandura, A., \& Walters, R. H. (1963). Social learning and personality development. New York: Rinehart \& Winston.

Brouwers, M. C., \& Sorrentino, R. M. (1993). Uncertainty orientation and protection motivation theory: The role of individual differences in health compliance. Journal of Personality \& Social Psychology, 65(1), 102-112.

Brown, K. M. (1999). Research/theories/models. Retrieved February 26, 2004, from http://hsc.usf.edu/ kmbrown/Research.htm

Cacioppo, J. T., \& Petty, R. E. (1979). Effects of message repetition and position on cognitive response, recall and persuasion. Journal of Personality and Social Psychology, 27, 97-109.

Caplan, G. (1974). Support systems and community mental health. New York: Behavioral Publications.

Clarke, R. (1999). A primer in diffusion of innovations theory. Retrieved January 10, 2004, from http://www.anu.edu.au/people/Roger.Clarke/SOS/InnDiff.html

Coalition of National Health Education Organizations. (2001). The health education profession in the 21st century: Progress report 1995-2001. Retrieved February 26, 2004, from http://www.hsc.usf.edu/CFH/cnheo/21st century.htm

Cobb, S. (1976). Social support as a moderator of life stress. Psychosomatic Medicine, 38, 300-314.

Diclemente, R. J., Crosby, R. A., \& Kegler, M. C. (Eds.) (2002). Emerging theories in health promotion practice and research: Strategies for improving public health. San Francisco: Jossey-Bass.

Festinger, L. (1957). A theory of cognitive dissonance. Stanford, CA: Stanford University Press.

Glanz, K., Lewis, M., \& Rimer, B. K. (Eds.) (1997). Health behavior and health education: Theory, research, and practice. San Francisco: Jossey-Bass.

Green, L., \& Kreuter, M. (1991). Health promotion planning (2nd ed.). Mountain View: Mayfield Publishing Co.

House, J. S. (1981). Work stress and social support. Retrieved January 10, 2004, from http://www.isss.org/lumLVB.htm

Jean Piaget Society. (2003, September 7). Internet resources. Retrieved January 11, 2004, from http://www.piaget.org/links.html

Kahn, R. L., \& Antonucci, T. C. (1980). Convoys over the life course: Attachment, roles and support. In P. B. Baltes and G. Brim (Eds.), Life-span development and behavior (pp. 253-83). New York: Academic Press.

Kreuter, M. W., \& Lezin, N. (2002). Social capital theory: Implications for community-based health promotion. In R. J. DiClemente, R. A. Crosby, \& M. C. Kegler (Eds.), Emerging theories in health promotion practice and research: Strategies for improving public health (pp. 228-254). San Francisco: Jossey-Bass.

Maddux, J. E., \& Rogers, R. W. (1983). Protection motivation theory and self-efficacy: A revised theory of fear appeals and attitude change. Journal of Experimental Social Psychology, 19, 469-479.

McKenzie, J. F., \& Smeltzer, J. L. (2001). Planning, implementing, and evaluating: Health promotion programs (3rd ed). Boston: Allyn and Bacon. 
National Institutes of Health. (1997). Theory at a glance. Retrieved February 26, 2004, from http://cancer.gov/cancerinformation/theory-at-a-glance

National Task Force on the Preparation and Practice of Health Educators. (1985). A framework for the development of competency-based curricula for entry level health educators. New York: National Commission for Health Education Credentialing, Inc.

Pajares, F. (2002). Overview of social cognitive theory and of self-efficacy. Retrieved January 11, 2004, from http://www.emory.edu/EDUCATION/mfp/eff.html

Petty, R. E., \& Cacioppo, J. T. (1981). Attitudes and persuasion-classic and contemporary approaches. Dubuque, IA: W. C. Brown Co. Publishers.

Petty, R. E., \& Caciopo, J. T. (1986). The elaboration likelihood model of persuasion. Advances in Experimental Social Psychology, 19, 123-205.

Prochaska, J. O., \& DiClemente, C. C. (1983). Stages and processes of self-change of smoking: Toward an integrative model of change. Journal of Consulting and Clinical Psychology, 51, 390-395.

Sirgy, M. J. (1984). Marketing as social behavior. New York: CBS Incorporated.

Strecher, V. J., \& Rosenstock, I. M. (1996). The health belief model. In K. Glanz, B. K. Rimer, M. Lewis (Eds.), Health behavior and health education: Theory, research, and practice (pp. 41-59). San Francisco: Jossey-Bass.

Triandis, H. C. (1977). Interpersonal behavior. Monterey, CA: Brooks/Cole.

Triandis, H. C. (1980). Values, attitudes, and interpersonal behavior. In H. Howe and M. Page (Eds.), Nebraska symposium on motivation 1979 (pp. 195-295). Lincoln, NE: University of Nebraska Press.

Triandis, H. C. (1994). Culture and social behavior. New York: McGraw-Hill Inc.

Triandis, H. C. (1995). Harry C. Triandis. American Psychologist, 50, 262-265.

Taub, A. (1998). Personal credentialing and the professionalization of health education. Journal of Health Education, 29, 121-25.

Von Bertalanffy, L. (1976). General systems: Foundations, development, applications. New York: George Braziller.

Wallston, B. S., Wallston, K. A., Kaplan, G. D., \& Maides, S. A. (1976). The development and validation of the health related locus of control (HLC) scale. Journal of Consulting and Clinical Psychology, 44, 580-585.

Wallston, K. A., Maides, S. A., \& Wallston, B. S. (1976). Health related information seeking as a function of health related locus of control and health value. Journal of Research in Personality, 10, 215-222.

Weinstein, N. D. (1988). The precaution adoption process. Health Psychology, 7, 355-386.

Zimmerman,G. L., Olsen, C. G., \& Bosworth, M. F. (2000, March 1). A stages of change approach to helping patients change behavior. American Family Physician. Retrieved January 10, 2004 from http://www.aafp.org/afp/20000301/1409.html

Author Information

Kathy DeBarr, PhD, Associate Professor

MPH Department

University of Illinois at Springfield

One University Plaza

Springfield, IL 62703

E-Mail: debarr@uis.edu 


\section{Appendix A}

2003 Articles and their Attendant Theories/Models

\section{Cognitive Dissonance Theory}

Wimer, J. (2003). Video intervention projects: Using technology and cognitive dissonance theory to enhance learning. American Journal of Health Education, 34, 372-374.

\section{Coping Theory}

Howard, D. E., Kaljee, L., Rachuba, L. T., \& Cross, S. I. (2003). Coping with youth violence:

Assessments by minority parents in public housing. American Journal of Health Behavior, 27, 483-492.

Major, D. A. (2003). Utilizing role theory to help employed parents cope with children's chronic illness. Health Education Research, 18, 45-57.

\section{Diffusion Theory}

Cross, D., Hall, M., \& Howat, P. (2003). Using theory to guide practice in children's pedestrian safety education. American Journal of Health Education, 34(1), 42-47. *

Hawks, S. R., \& Madanat, H. N. (2003). Stemming racial and ethnic disparities in the rising tide of obesity. American Journal of Health Education, 34(2), 90-96. *

Lafferty, C. K., Mahoney, C. A., \& Thombs, D. L. (2003). Diffusion of a developmental asset-building initiative in public schools. American Journal of Health Behavior, 27(Suppl. 1), S35-S44. *

Osganian, S. K., Parcel, G. S., \& Stone, E. J. (2003). Institutionalization of a school health promotion program: Background and rationale of the CATCH-ON study. Health Education \& Behavior 30, 410-417.

Riley, B. L. (2003). Dissemination of heart health promotion in the Ontario public health system: 19891999. Health Education Research, 18(1), 15-31. *

\section{Elaboration Likelihood Model}

Kreuter, M. W., \& Wray, R. J. (2003). Tailored and targeted health communication: Strategies for enhancing information relevance. American Journal of Health Behavior, 27(Suppl. 3), S227S232.

\section{Health Belief Model}

Burton, N. W., Turrell, G., \& Oldenburg, B. (2003). Participation in recreational physical activity: Why do socioeconomic groups differ? Health Education \& Behavior, 30, 225-244.

Cross, D., Hall, M., \& Howat, P. (2003). Using theory to guide practice in children's pedestrian safety education. American Journal of Health Education, 34(5), 42-47. *

Hammig, B., \& Moranetz, C. A. (2003). Gender differences in health beliefs concerning violent vicitimization by strangers. American Journal of Health Education, 34, 206-211.

Rhodes, S. D., Grimley, D. M., \& Hergenrather, K. C. (2003). Integrating behavioral theory to understand hepatitis B vaccination among men who have sex with men. American Journal of Health Behavior 27, 291-300.

\section{Locus of Control}

Chng, C. L., Neill, K., \& Fogle, P. (2003). Predictors of college students’ use of complementary and alternative medicine, American Journal of Health Education 34, 267-271. 


\section{Organizational Theory}

Pavis, S., Constable, H., \& Masters, H. (2003). Multi-agency, multi-professional work: experiences from a drug prevention project. Health Education Research, 18, 717-728.

Riley, B. L., Taylor, S. M., \& Elliott, S. J. (2003). Organizational capacity and implementation change: a comparative case study of heart health promotion in Ontario public health agencies. Health Education Research, 18, 754-769.

\section{Piaget's Theory of Child Development}

Cross, D., Hall, M., \& Howat, P. (2003). Using theory to guide practice in children's pedestrian safety education. American Journal of Health Education, 34(5), 42-47. *

\section{Precaution Adoption Process Model}

Sharp, K., \& Thombs, D. L. (2003). A cluster analytic study of osteoprotective behavior in undergraduates. American Journal of Health Behavior, 27, 364-372.

\section{Precede-Proceed}

*Cross, D., Hall, M., \& Howat, P. (2003). Using theory to guide practice in children's pedestrian safety education. American Journal of Health Education, 34(5), 42-47.

\section{Protection Motivation Theory}

Houlding, C., \& Davidson, R. (2003) Beliefs as predictors of condom use by injecting drug users in treatment. Health Education Research, 18, 145-155.

\section{Social Cognitive Theory/Social Learning Theory}

Blue, C. L., Black, D. R., Conrad, K., \& Gretebeck, K. A.(2003). Beliefs of blue-collarworkers: Stage of readiness for exercise. American Journal of Health Behavior, 27, 408-420. *

Burton, N. W., Turrell, G., Oldenburg, B. (2003). Participation in recreational physical activity: Why do socioeconomic groups differ? Health Education \& Behavior, 30, 225-244.

Copeland, L.A., Blow, F. C., \& Barry, K. L. (2003). Health care utilization by older alcohol-using veterans: Effects of a brief intervention to reduce at-risk drinking. Health Education \& Behavior, 30, 305-321.

Cross, D., Hall, M., \& Howat, P. (2003). Using theory to guide practice in children's pedestrian safety education. American Journal of Health Education, 34(5), 42-47. *

Godin, G., Michaud, F., Alary, M., Otis, J., Masse, B., Fortin, C., Gagnon, M-P., \& Gagnon, H. (2003). Evaluation of an HIV and STD prevention program for adolescents in juvenile rehabilitation centers. Health Education \& Behavior, 30, 601-614. *

Hawks, S. R., \& Madanat, H. N. (2003). Stemming racial and ethnic disparities in the rising tide of obesity. American Journal of Health Education, 34(2), 90-96. *

Lafferty, C. K., Mahoney, C. A., \& Thombs, D. L. (2003). Diffusion of a developmental asset-building initiative in public schools. American Journal of Health Behavior, 27(Suppl. 1), S35-S44. *

Petosa, R. L., Suminski, R., \& Hortz, B. (2003). Predicting vigorous physical activity using social cognitive theory. American Journal of Health Behavior, 27, 301-310.

Rhodes, S. D., Grimley, D. M., \& Hergenrather, K. C. (2003). Integrating behavioral theory to understand hepatitis B vaccination among men who have sex with men. American Journal of Health Behavior, 27, 291-300.

Rimal, R. N. (2003). Intergenerational transmission of health: The role of intrapersonal, interpersonal, and commuinicative factors. Health Education \& Behavior, 30(1), 10-28.

Wallace, L. S. (2003). Correlates of lifetime physical activity in young women. American Journal of Health Education, 34(1), 41-46. * 


\section{Social Support}

Fang, X., Li, X., Stanton, B., \& Dong, Q. (2003). Social network positions and smoking experimentation among Chinese adolescents. American Journal of Health Behavior, 27, 257-267.

Gallant, M. P. (2003). The influence of social support on chronic illness self-management: A review and directions for research. Health Education \& Behavior, 30, 170-195.

Hyyppa, M.T., \& Maki, J. (2003) Social participation and health in a community rich in stock of social capital. Health Education Research. 18, 770-779.

Okun, M. A., Ruehlman, L., K. P., Lutz, R., Fairholme, C., \& Schaub, R. (2003). Social support and social norms: Do both contribute to predicting leisure-time exercise? American Journal of Health Behavior, 27, 493-507. *

\section{Systems Theory}

Best, A., Moor, G., Holmes, B., Clark, P. I., Bruce, T., Leischow, S., Buchholz, K., \& Krajnak, J. (2003). Health promotion dissemination and systems thinking: Towards an integrative model. American Journal of Health Behavior, 27(Suppl. 3), S206-S216. *

\section{Theory of Interpersonal Behavior}

Godin, G., Michaud, F., Alary, M., Otis, J., Masse, B., Fortin, C., Gagnon, M-P., \& Gagnon, H. (2003). Evaluation of an HIV and STD prevention program for adolescents in juvenile rehabilitation centers. Health Education \& Behavior, 30, 601-614.

\section{Theory of Reasoned Action/ Theory of Planned Behavior}

Abroms, L., Jorgensen, C. M., Southwell, B. G., Geller, A. C., \& Emmons, K. M. (2003). Gender differences in young adults' beliefs about sunscreen use. Health Education \& Behavior, 30, 2943.

Blanchard, C. M., Rhodes, R. E., Nehl, E., Fisher, J., Sparling, P., \& Courneya, K. S. (2003). Ethnicity and the theory of planned behavior in the exercise domain. American Journal of Health Behavior 27, 579-591.

Blue, C. L., Black, D. R., Conrad, K., \& Gretebeck, K. A.(2003). Beliefs of blue-collar workers: Stage of readiness for exercise. American Journal of Health Behavior, 27, 408-420. *

Burton, N. W., Turrell, G., \& Oldenburg, B. (2003). Participation in recreational physical activity: Why do socioeconomic groups differ? Health Education \& Behavior, 30, 225-244.

Evans, D. Norman, P. (2003). Predicting adolescent pedestrians' road-crossing intentions: an application and extension of the theory of planned behaviour. Health Education Research, 18, 267-277.

Godin, G., Michaud, F., Alary, M., Otis, J., Masse, B., Fortin, C., Gagnon, M-P., \& Gagnon, H. (2003). Evaluation of an HIV and STD prevention program for adolescents in juvenile rehabilitation centers. Health Education \& Behavior, 30, 601-614. *

Gottlieb, N. H., Goldstein, A. O. (2003). State legislators' beliefs about legislation that restricts youth access to tobacco products. Health Education \& Behavior, 30, 209-224.

Hawks, S. R., \& Madanat, H. N. (2003). Stemming racial and ethnic disparities in the rising tide of obesity. American Journal of Health Education, 34(2), 90-96. *

Kassem, N. O., Lee, J. W., Modeste, N. N. \& Johnston, P. K (2003). Understanding soft drink consumption among female adolescents using the theory of planned behavior. Health Education Research, 18, 278-291.

Masalu, J. R., Astrom, A. N. (2003). The use of the theory of planned behavior to explore beliefs about sugar restriction. American Journal of Health Behavior 27, 15-24.

Okun, M. A., Ruehlman, L., Karoly, P., Lutz, R., Fairholme, C., \& Schaub, R. (2003). Social support and social norms: Do both contribute to predicting leisure-time exercise? American Journal of Health Behavior, 27, 493-507. *

Schulman, J. A., \& Karney, B. R. (2003). Gender and attitudes toward nutrition in prospective physicians. American Journal of Health Behavior, 27, 623-632. 
Spatz, B. A., Thombs, D. L., Byrne, J., \& Page., B. J. (2003). Use of the theory of planned behavior to explain HRT decisions. American Journal of Health Behavior, 27, 445-455.

\section{Transtheoretical Model}

Blue, C. L., Black, D. R., Conrad, K., \& Gretebeck, K. A.(2003). Beliefs of blue-collar workers: Stage of readiness for exercise. American Journal of Health Behavior, 27, 408-420. *

Copeland, L.A., Blow, F. C., and Barry, K. L. (2003). Health care utilization by older alcohol-using veterans: Effects of a brief intervention to reduce at-risk drinking. Health Education \& Behavior 30, 305-321.

Dunnagan, T., Haynes, G., Linkenbach, J., \& Shatwell, P. (2003). Developing theoretical and environmental policy for underage drinking. American Journal of Health Behavior, 27(5), 508523.

Hawks, S. R., \& Madanat, H. N. (2003). Stemming racial and ethnic disparities in the rising tide of obesity. American Journal of Health Education, 34(2), 90-96. *

John, J. H., Yudkin, P. L., Neil, H. A. W. \& Ziebland, S. (2003). Does stage of change predict outcome in a primary-care intervention to encourage an increase in fruit and vegetable consumption? Health Education Research, 18, 429-438.

Ma, J.. Betts, N. M., Horacek, T., Georgiou, C. \& White, A. (2003). Assessing stages of change for fruit and vegetable intake in young adults: a combination of traditional staging algorithms and foodfrequency questionnaires. Health Education Research, 18, 224-236.

Marttila, J., \& Nupponen, R. (2003). Assessing stage of change for physical activity: how congruent are parallel methods? Health Education Research, 18, 419-428.

O’Hea, E. L., Wood, K. B., \& Brantley, P. J. (2003). The transtheoretical model: Gender differences across 3 health behaviors. American Journal of Health Behavior, 27, 645-656.

Price, J. H., Yingling, F., Dake, J. A., \& Telljohann, S. K. (2003). Adolescent smoking cessation services of school-based health centers. Health Education \& Behavior, 30, 196-208.

Resnicow, K., McCarty, F., Baranowski, T. (2003). Are precontemplators less likely to change their dietary behavior? A prospective analysis. Health Education Research, 18, 693-705.

Rhodes, S. D., Grimley, D. M., \& Hergenrather, K. C. (2003). Integrating behavioral theory to understand hepatitis B vaccination among men who have sex with men. American Journal of Health Behavior, 27, 291-300.

Tai-Seale, T. (2003). Stage of change specific triggers and barriers to moderate physical activity. American Journal of Health Behavior, 27, 219-227.

Taylor, C. L. C., Boudreaux, E. D., Jeffries, S. K., Scarinci, I. C., \& Brantley, P. J. (2003). Applying exercise stage of change to a low-income underserved population. American Journal of Health Behavior, 27, 99-107.

Thu Ha, B. T., Jayasuriya, R., \& Owen, N. (2003). Male involvement in family planning in rural Vietnam: an application of the transtheoretical model. Health Education Research, 18,171-180.

Trauth, J. M., Ling, B. S., Weissfeld, J. L., Schoen, R. E., \& Hayran, M. (2003). Using the transtheoretical model to stage screening behavior for colorectal cancer. Health Education \& Behavior, 30, 322-336.

Vandelanotte, C., \& De Bourdeaudhuij, I. (2003) Acceptability and feasibility of a computer-tailored physical activity intervention using stages of change: project FAITH. Health Education Research. 18, 304-317.

Wallace, L. S. (2003). Correlates of lifetime physical activity in young women. American Journal of Health Education, 34(1) 41-46.*

*All starred entries use more than one theory. 


\section{Appendix B}

Depiction of the Similarities Found within the Individual and Interpersonal Health Theories

\begin{tabular}{|c|c|c|c|c|c|}
\hline Theory/Model & $\begin{array}{c}\text { Perception of Threat/ } \\
\text { Expectations }\end{array}$ & $\begin{array}{l}\text { Efficacy } \\
\text { Internal } \\
\text { Control }\end{array}$ & $\begin{array}{c}\text { Outcome } \\
\text { Expectancy }\end{array}$ & $\begin{array}{c}\text { Enabling } \\
\text { Factors or } \\
\text { Barriers }\end{array}$ & Others \\
\hline Health Belief Model & $\begin{array}{l}\text { Perceived Threat } \\
\text { Susceptibility } \\
\text { Severity }\end{array}$ & $\begin{array}{l}\text { Self- } \\
\text { Efficacy }\end{array}$ & & $\begin{array}{l}\text { Benefits } \\
\text { Barriers }\end{array}$ & \\
\hline $\begin{array}{l}\text { Theory of Reasoned } \\
\text { Action/ Planned } \\
\text { Behavior }\end{array}$ & $\begin{array}{l}\text { Outcome Expectancy } \\
\text { Evaluation of } \\
\text { Likelihood of } \\
\text { Expectancy }\end{array}$ & $\begin{array}{l}\text { Control } \\
\text { beliefs }\end{array}$ & & & $\begin{array}{l}\text { Subjective Norm } \\
\text { Normative Beliefs } \\
\text { Salient referents } \\
\text { Motivation to } \\
\text { comply with } \\
\text { referents }\end{array}$ \\
\hline $\begin{array}{l}\text { Protection } \\
\text { Motivation Theory }\end{array}$ & $\begin{array}{l}\text { Threat appraisal } \\
\text { Severity } \\
\text { Vulnerability }\end{array}$ & $\begin{array}{l}\text { Coping } \\
\text { appraisal } \\
\text { Self-efficacy } \\
\text { Response- } \\
\text { efficacy } \\
\end{array}$ & & & \\
\hline $\begin{array}{l}\text { Social Learning } \\
\text { Theory }\end{array}$ & & Self-efficacy & & & $\begin{array}{l}\text { Modeling } \\
\text { Vicarious learning }\end{array}$ \\
\hline $\begin{array}{l}\text { Theory of } \\
\text { Interpersonal } \\
\text { Behavior }\end{array}$ & & $\begin{array}{l}\text { Personal } \\
\text { factors } \\
\text { Habit }\end{array}$ & & $\begin{array}{l}\text { Facilitating } \\
\text { conditions }\end{array}$ & Social \\
\hline $\begin{array}{l}\text { Social Support and } \\
\text { Coping }\end{array}$ & & & & & $\begin{array}{l}\text { Supportive } \\
\text { behaviors } \\
\text { Emotional support } \\
\text { Appraisal support } \\
\text { Informational } \\
\text { support } \\
\text { Instrumental } \\
\text { support } \\
\text { Social capital }\end{array}$ \\
\hline Locus of Control & Expectancy & & & $\begin{array}{l}\text { Re- } \\
\text { inforcement }\end{array}$ & $\begin{array}{l}\text { External locus of } \\
\text { control } \\
\text { Powerful others }\end{array}$ \\
\hline $\begin{array}{l}\text { Elaboration } \\
\text { Likelihood Model }\end{array}$ & & $\begin{array}{l}\text { Ability to } \\
\text { process, } \\
\text { Nature of } \\
\text { cognitive } \\
\text { processing, } \\
\text { Persistence, } \\
\text { Resistance }\end{array}$ & & $\begin{array}{l}\text { Peripheral } \\
\text { cue present }\end{array}$ & \\
\hline
\end{tabular}

